\author{
Marquette University \\ e-Publications@Marquette
}

College of Communication Faculty Research

and Publications

Communication, College of

$1-2016$

\title{
Chair Support, Faculty Entrepreneurship, and the Teaching of Statistical Reasoning to Journalism Undergraduates in the United States
}

Robert J. Griffin

Marquette University, robert.griffın@marquette.edu

Sharon Dunwoody

University of Wisconsin - Madison

Follow this and additional works at: https://epublications.marquette.edu/comm_fac

Part of the Communication Commons

\section{Recommended Citation}

Griffin, Robert J. and Dunwoody, Sharon, "Chair Support, Faculty Entrepreneurship, and the Teaching of Statistical Reasoning to Journalism Undergraduates in the United States" (2016). College of Communication Faculty Research and Publications. 406.

https://epublications.marquette.edu/comm_fac/406 


\title{
Chair Support, Faculty Entrepreneurship, and the Teaching of Statistical Reasoning to Journalism Undergraduates in the United States
}

\author{
Robert J. Griffin \\ Journalism and Media Studies, Marquette University \\ Milwaukee, WI \\ Sharon Dunwoody \\ School of Journalism and Mass Communication, \\ University of Wisconsin - Madison \\ Madison, WI
}

\begin{abstract}
Statistical reasoning is not the same as doing calculations. Instead, it involves cognitive skills such as the ability to think critically and systematically with data, skills important for everyday news work and essential for the era of data journalism. Twin surveys of the chairs of


undergraduate journalism programs in the United States, conducted 11 years apart, revealed that those who perceived benefits from statistical reasoning instruction were more likely to reward entrepreneurship (faculty attempts to integrate this instruction into their classes), but with slow gains over time in the fairly small number of such faculty. Being consistent with university goals in statistical reasoning instruction appeared to motivate chairs' reward decisions in both waves. Increasingly, they took into account what they saw as the general value of statistical reasoning for their students and the competitive edge it could give them in the journalism job market. Perceived constraints to teaching this content had no apparent overall impact on reward decisions.

Keywords: Statistics, statistical reasoning, numeracy, journalism education, data journalism, journalism faculty, journalism administration, journalism students, data journalism

\section{Introduction}

Former New York Times reporter Nate Silver has become something of a journalistic rock star, with his website FiveThirtyEight (http://fivethirtyeight.com/), newly lodged at ESPN, churning out one statistically driven story after another. Equally visible is former Washington Post blogger Ezra Klein's Vox.com (http://www.vox.com/), a news site emphasizing explanation of the news in ways heavily reliant on statistical patterns. Along with a promised surge in 'data journalism', events such as these might lead one to assume that American journalists are exercising a long-dormant interest in employing statistics in their work.

But history suggests otherwise, that journalists in the United States instead have long expressed little affinity for statistical reasoning. In fact, many appear to have embarked on a reporting career in part because they view writing and quantitative reasoning as antithetical to one another and believe that opting into the former will absolve them of the latter.

Indeed, working journalists are considerably less likely than journalism professors to believe that beginning reporters should be statistically literate. In a Poynter Institute survey, Finberg and Klinger (2014) found that 73 percent of journalism educators rated the ability to analyze and synthesize large amounts of data as an important or very important skill for beginning journalists to have. Only 55 percent of journalism professionals and 56 percent of journalism managers

Journalism: Theory, Practice \& Criticism, Vol. 17, No. 1 (January 2016): pg. 97-118. DOI. This article is @ SAGE Publications and permission has been granted for this version to appear in e-Publications@Marquette. SAGE Publications does not grant permission for this article to be further copied/distributed or hosted elsewhere without the express permission from SAGE Publications. 
rated that skill as highly. A larger gap exists in a skill even more closely associated with statistical reasoning: the ability to interpret statistical data and graphics. About 80 percent of the journalism educators rated that skill as important or very important for beginning journalists, whereas only 59 percent of working journalists and 62 percent of managers did so. 1

'Given the large amounts of data available on the Internet and the growing importance of presenting information in a pleasing and informative visual manner, the gap between educators and professionals is disturbing', commented Finberg and Klinger (2014: 14). 'The ability to make sense of our complex world by distilling meaningful information from the vast river of data is one of the great values professional journalists can offer their audience'.

The drumbeat of advice urging journalists to become more statistically literate seems to be growing ever louder. Starting in the late 1990s, Dunwoody and Griffin (2013) had asked if US journalism schools had responded to this call. In two surveys, a decade apart, they queried journalism school chairs and directors about their units' pedagogical commitments to statistical reasoning training.

Following from those results, and using the same datasets, this article further examines some key factors emerging from that study that appear to affect the presence/absence of statistical reasoning education in journalism programs around the country. Specifically, this article next describes the importance of statistical reasoning to journalists and journalism education. Then, guided by a pair of research questions, analysis explores several institutional and administrative variables that may contribute to the integration of statistical reasoning training in undergraduate journalism programs. Finally, with our results as a catalyst, we offer some suggestions that may help administrators and faculty provide $j$-students with that instruction.

\section{Journalists and statistical reasoning}

Statistical reasoning is not the same as doing statistical calculations. Fundamentally, statistical reasoning is 'the way people reason with statistical ideas and make sense of statistical information', 
as Garfield and Gal (1999: 207) observe. In an era of big data and computer-assisted reporting, statistical reasoning skills are, increasingly, an essential part of a journalist's cognitive toolkit. Yet, journalists often struggle with interpreting statistical information for themselves and their audiences. For example, while Maier (2002) found many mathematical representations in a content analysis of news stories, he also found numerous errors in their use. And explorations of reporters' willingness to employ numbers and statistical representations in stories find that math anxiety is common and serves as a major roadblock (Curtin and Maier, 2001; Maier, 2003).

Even science journalists - whose focus on scientific research might lead them to emphasize statistical reasoning more than other reporters - apparently default to only basic statistical representations. In one study of newspaper stories about scientific research in Dutch newspapers, the coauthors found frequent employment of basic statistical representations such as percentages and proportions but almost no effort to explain the research covered by utilizing more complex statistical representations such as statistical significance, correlation, or measurement error (Hijmans et al., 2003).

Although studies of statistical literacy among journalists are virtually nonexistent, national surveys over the years have demonstrated considerable limitations in Americans' grasp of both numeracy and statistical reasoning, a condition that today's journalists undoubtedly share. Level of education, not surprisingly, is a predictor of statistical performance in the classroom (Galesic and GarciaRetamero, 2010), but Garfield (1998) cautions that students who learn to handle statistics well in school often perform poorly when called on to use that knowledge in real-world settings.

Although one can find occasional efforts to embed statistical skill-building in journalism training over the decades - from journalistturned-professor Philip Meyer's (1973) book Precision Journalism to science and medical reporters Victor Cohn and Lewis Cope's (2001) volume News \& Numbers to the rare funded effort to create statistical training modules for the journalism classroom (see, e.g., Livingston and Voakes, 2005) - evidence suggests that formal journalism training in US universities gives such instruction short shrift (Cusatis and Martin-Kratzer, 2010; Dunwoody and Griffin, 2013). This is despite the 
fact that the body that accredits university journalism programs in the United States requires majors to be able to 'apply basic numerical and statistical concepts' (Accrediting Council on Education in Journalism and Mass Communication, 2012; also see Henderson and Christ, 2014). One scholar long noted for championing the introduction of math and statistical training in journalism, Paul Voakes (2006), readily acknowledges the challenges presented by this goal. 'In most lists of goals or competencies in journalism and mass communication', he notes, 'mathematic competence seems to bring up the rear. This is the element of a communication education that seems most foreign to most communication educators' (p. 261).

The most current surveys of journalism program chairs and directors provide evidence of continued wariness about providing statistical reasoning instruction within the journalism curriculum. For example, while chairs felt that statistical training is important and a plurality indicated it should be offered across their curriculums by embedding it in a variety of courses, they expressed concern about the ability of their faculty members to accomplish that. They also overwhelmingly expressed the belief that their students would actively avoid such material and, worse, nearly half believed that their students would be intellectually unable to handle such an instruction (Dunwoody and Griffin, 2013). While these chairs offered some evidence for the former, they are probably wrong about the latter. Examination of journalism student Scholastic Aptitude Test (SAT) scores finds that incoming journalism undergraduates are as well equipped to tackle mathematical and statistical instruction as any undergraduate (Becker and Graf, 1994; Dunwoody and Griffin, 2013). 2 In the following analysis, we seek to explore a set of factors that might underlie these perceptions and curricular decisions.

\section{Research questions}

Previous surveys had shown that, among a plurality of the journalism department administrators (41\% in 1997, 47\% in 2008), the preferred method of teaching their students statistical reasoning was to integrate this instruction across the array of journalism courses (Dunwoody and Griffin, 2013). What facilitates this kind of instruction? In what kinds of programs is it found? 
To help shed light on these matters, this study will examine a couple of ways in which statistical reasoning instruction might find its way into the journalism curriculum: (1) the extent that courses which include this instruction are integrated more formally into the curriculum and (2) individual faculty attempts to teach statistical reasoning to journalism students in their classes (what we will call 'faculty entrepreneurship').

So, the first research question is: What structural variables (e.g. department size) might be associated with the offering of statistical reasoning instruction within undergraduate journalism education?

The second research question is: How might administrative support influence faculty entrepreneurship in teaching statistical reasoning and the integration of statistical reasoning into the journalism curriculum?

\section{Method}

\section{Sampling}

Sample surveys of the administrators (e.g. department chairs) of college-level journalism programs in the United States were conducted in 1997 and 2008. (Regardless of their administrative titles, they will be referred to as 'chairs'.) The probability sample was derived from the programs listed in the Journalism and Mass Communication Directory, published by the Association for Education in Journalism and Mass Communication, and the Dow Jones Journalism and Career Scholarship Guide. 3

The 1997 study was a surface mail survey of 219 chairs sampled out of the population of 430. This survey yielded 164 respondents (a 75\% response rate). The follow-up wave, in 2008, used the same sample of programs and the same questionnaire in order to make the two surveys as comparable as possible. Four of the programs had ceased to exist in the interim, leaving a sample of 215. Nearly all these programs (195) had changed chairs since 1997. A combination of surface mail and online procedures was used for the 2008 survey, which yielded 135 respondents (a 63\% response rate). 
NOT THE PUBLISHED VERSION; this is the author's final, peer-reviewed manuscript. The published version may be accessed by following the link in the citation at the bottom of the page.

Both surveys were approved by the university's Institutional Review Board.

\section{First wave}

In spring 1997, the sampled chairs were mailed personalized first-contact letters describing the study, in advance of their being sent the questionnaires, personalized cover-letters, and stamped return envelopes. All personally identifying information was removed immediately from the returned questionnaires. Over a 3-month period, those chairs who had not responded were sent up to three follow-up mailings of the questionnaire, including personalized, follow-up coverletters and stamped return envelopes. Those who specifically declined to participate were not re-contacted.

\section{Second wave}

In spring 2008, each current chair of the sampled programs was sent an advance personalized letter both by US mail and by email notifying him or her of the upcoming online survey. The advance surface mailing included a stamped, return envelope for the respondents to use in case they wanted to request a hard-copy questionnaire, or to state that they did not want to participate further. Chairs were later sent an email with a link to the online questionnaire or, in cases where they had requested it, they were mailed hard-copies of the questionnaire, return envelopes, and related materials. Respondents were tracked without associating them with any questionnaires, and questionnaires were completed anonymously. In the following months, reminders and necessary materials were sent via email and surface mail to chairs who had not responded. Of the 135 chairs, 96 (71\%) completed the questionnaire online and the remainder on hard copy. Only 20 respondents in the second wave were the same individuals as in the first wave. Given that, and the 11 years that had passed between waves, the two waves of respondents were treated as two independent groups. 
NOT THE PUBLISHED VERSION; this is the author's final, peer-reviewed manuscript. The published version may be accessed by following the link in the citation at the bottom of the page.

\section{Questionnaire}

Questionnaires took, on average, about 10 minutes to complete. At the start of the questionnaire, the chairs were provided with the following definition of statistical reasoning (emphasis in the original):

In this survey we are interested in your ideas about the extent to which your undergraduate journalism students should be introduced to statistics and especially to statistical reasoning. By 'statistical reasoning' we don't mean their ability to compute statistical tests. Instead, we mean their ability to think systematically and reason using numerical data, for example:

to assess critically the quality of data;

to apply data appropriately to problem solving;

to understand the limits to generalizability;

to understand probability and risk;

to recognize when better data and information are needed for decision-making (e.g., when the data provided are incomplete or not comparable), and to diagnose what information is missing.

The chairs were then given a series of statements related to statistical reasoning education for journalism students, and asked to respond to each using a 5-point Likert-type scale. The items were introduced as follows:

The following are statements that some professors and administrators have made about the teaching of statistical methods and statistical reasoning to undergraduates in journalism. Please indicate the strength of your agreement or disagreement by checking one response to the right of each one.

Scale responses to each item were as follows: (1) strongly disagree, (2) disagree, (3) feel neutral, (4) agree, and (5) strongly agree. 
NOT THE PUBLISHED VERSION; this is the author's final, peer-reviewed manuscript. The published version may be accessed by following the link in the citation at the bottom of the page.

\section{Measures}

Among the Likert-type scaled items were measures assessing perceptions of the potential benefits of statistical reasoning instruction for journalism students, the perceived constraints to providing this education, and the chairs' support for faculty efforts at statistical reasoning instruction. In the narrative below, the percentage of chairs who agreed or strongly agreed with each of these items is shown in parentheses, for the first and second wave respectively, after each statement from the questionnaires (see Appendix 1 for details, including information about 95\% confidence intervals). None of the differences across waves was statistically significant.

\section{Benefits}

Three items tapped the chairs' views of the potential benefits to the students of teaching statistical reasoning. The inherent value to the students was represented by the item 'It is important for our journalism students to be able to reason statistically' $(91.5 \%, 91.1 \%)$. Perception of instrumental value for the students' employability was measured by 'Statistical reasoning skills give students a competitive edge in the journalism job market' $(67.0 \%, 71.8 \%)$. Consistency with university policy toward student learning of statistical reasoning was represented by 'Our university's goal is to integrate statistical reasoning into the curriculum' $(23.2 \%, 31.8 \%)$.

\section{Constraints}

Three items asked chairs to respond to student and staff circumstances that could directly pose difficulties in teaching statistical reasoning in journalism classrooms. Two items dealt with studentrelated considerations: 'Most of our journalism students lack the mathematical aptitude required to do well in the basic statistics course at our university' $(47.6 \%, 42.3 \%)$ and 'Most of our journalism students would rather not learn statistical reasoning' $(77.5 \%, 78.5 \%)$. A potential challenge for faculty was addressed with: 'Most of my faculty would have difficulty teaching statistical reasoning as part of their journalism classes' $(53.1 \%, 53.3 \%)$. 
Factor analysis of the above six items, employing principal components analysis and Varimax rotation in the Statistical Package for the Social Sciences (IBM SPSS), revealed that the items loaded as expected into the two dimensions, one representing constraints $($ alpha $=.60)$ and the other benefits (alpha $=.62)$. A companion factor analysis with oblique rotation found essentially the same results.

\section{Chair support}

The administrator's support for teaching of statistical reasoning was measured with: 'To the extent I can, I reward faculty who bring statistical reasoning into their classes' $(25.6 \%, 28.9 \%)$.

\section{Faculty entrepreneurship}

The questionnaire also asked the chair how many (if any) 'individual professors at your school [have] done anything creative (whether successful or not) to teach statistical reasoning to journalism students'. Responses ranged from 0 through 10 faculty, although the most common responses were none (primarily) or one (Wave 1 mean $=.51$, Wave $2=1.01, t_{297}=4.32, p<.001$ ). This variable was later transformed $\left(\log _{10}\right.$ of $\left.X+1\right)$ for the analyses to overcome a strong positive skew (Wave 1 mean $=.16$, Wave $2=.26, t_{297}=5.20$, $p<.001)$.

\section{Integration of statistical reasoning instruction}

The chairs also indicated whether or not their department offered a course that included the teaching of statistical reasoning to journalism undergraduates (e.g. in a computer-assisted reporting or research methods course). Scale values were as follows: (0) no; (1) yes, elective; (2) yes, required for most or all journalism students (Wave 1 mean $=.96$, Wave $2=.96, t_{297}=.06$, ns). Overall, about 36 percent of the programs required such a course, and about 40 percent offered no such course, these proportions remaining essentially unchanged over time. 
NOT THE PUBLISHED VERSION; this is the author's final, peer-reviewed manuscript. The published version may be accessed by following the link in the citation at the bottom of the page.

\section{Covariates}

Structural variables, which served as control variables, included the size of the program (the number of fulltime faculty, the number of fulltime students), the highest degree offered (bachelor's, master's, doctorate), and the tightness of the curriculum. Curricular constraints ('tightness') were addressed with the following Likert-type scaled item: 'The journalism curriculum is too tight to offer in-house instruction in statistical methods and their applications' $(48.8 \%, 40.0 \%) .{ }^{4}$ Chairs were not asked to specify further whether they perceived curricular tightness as primarily a matter of limited student choices, or as a matter of constraints on faculty adding new courses or content to the

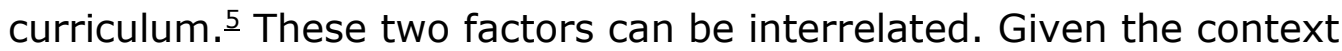
of the questionnaire, our interpretation will essentially be the latter.

The wave of the survey was also used as a covariate in analyses that combined data from the first and second waves. The method of surveying (mail, online) in the second wave had no statistically significant relationship with responses to items used in this analysis.

The questionnaire also gathered information about various other characteristics related to statistical reasoning instruction in the chairs' journalism programs and their preferences in that regard.

\section{Analysis}

The IBM Statistical Package for the Social Sciences and its AMOS structural equation modeling (SEM) program were used for the analysis. The fairly small amounts of missing data were replaced with scale means. To efficiently control for the effects of the covariate variables (above) in the AMOS analyses, IBM SPSS multiple regression was used first to produce a standardized, residualized version of each variable to be used in the AMOS analyses (each variable had been regressed on the covariates above, and the standardized residuals were then saved to be used in the AMOS analyses). The result, for example, is that variance in faculty entrepreneurship (differences in the number of professors in each department who have tried teaching statistical reasoning) is effectively adjusted to account for differences in the number of fulltime faculty across the various departments, as 
NOT THE PUBLISHED VERSION; this is the author's final, peer-reviewed manuscript. The published version may be accessed by following the link in the citation at the bottom of the page.

well as by the other control variables. Bootstrapping was used in the AMOS analyses.

\section{Results}

\section{Structural factors and statistical reasoning instruction}

The first research question wondered what structural variables might be associated with the offering of statistical reasoning instruction within undergraduate journalism education. In other words, in what kinds of programs is one more likely to find such an instruction? This exploration of the offering of statistical reasoning instruction will examine faculty entrepreneurship (individual attempts to teach statistical reasoning to journalism students) as well as statistical reasoning integration (the extent that courses which feature this instruction are integrated into the curriculum).

Table 1 shows that, over time, larger programs and those which offered more advanced degrees provided more integration of statistical reasoning instruction. Commonly these would be much the same kinds of programs. ${ }^{6}$ Similarly, faculty entrepreneurship was more common among programs which offered higher degrees (they are likely also to be the larger programs). Curricular tightness is associated with less integration of statistical reasoning instruction within the journalism programs, and with limited faculty entrepreneurship in at least the first wave of the study. Tightness is not associated with the size of the program $(r=.01, \mathrm{~ns})$ nor with the level of degree offered $(r=-.03$, ns). 
NOT THE PUBLISHED VERSION; this is the author's final, peer-reviewed manuscript. The published version may be accessed by following the link in the citation at the bottom of the page.

Table 1. Correlation of structural control variables with Integration of Statistical Reasoning (S.R.) Instruction and Faculty S.R. Entrepreneurship in Journalism undergraduate programs.

Table I. Correlation of structural control variables with Integration of Statistical Reasoning (S.R.) Instruction and Faculty S.R. Entrepreneurship in Journalism undergraduate programs.

\begin{tabular}{|c|c|c|c|c|c|}
\hline & \multicolumn{3}{|c|}{ Correlations: With S.R. Integration ${ }^{2}$} & \multicolumn{2}{|c|}{ With S.R. Entrepreneurship ${ }^{b}$} \\
\hline & $\begin{array}{l}\text { Program } \\
\text { size }^{c}\end{array}$ & $\begin{array}{l}\text { Highest degree } \\
\text { offered }\end{array}$ & $\begin{array}{l}\text { Curricular } \\
\text { tightness }\end{array}$ & $\begin{array}{l}\text { Highest degree } \\
\text { offered }^{d}\end{array}$ & $\begin{array}{l}\text { Curricular } \\
\text { tightnesse }\end{array}$ \\
\hline $\begin{array}{l}\text { Both waves } \\
\text { combined }(N=299)\end{array}$ & $.20^{\text {toplesf }}$ & $18^{\text {expoly }}$ & $-.23^{\text {molowf }}$ & $.18^{\mathrm{k} / \mathrm{kg}}$ & $-.14 \%$ \\
\hline First wave $(n=164)$ & $.23^{\text {*k* }}$ & $.17^{*}$ & $-.26^{* \neq 1 *}$ & $.17^{\text {*h }}$ & -.21 *tक \\
\hline $\begin{array}{l}\text { Second wave } \\
(n=135)\end{array}$ & $.18 *$ & $.20^{*}$ & $-.20^{*}$ & $.19^{\text {th }}$ & $-.09^{h}$ \\
\hline
\end{tabular}

"Whether department offers a course featuring statistical reasoning instruction: (0) no; (1) elective: (2) required for most or all journalism students.

'The number professors who have 'done anything creative (whether successful or not) to teach statistical reasoning to journalism students', as reported by the chair. The variable was log-transformed (see the article text) and controlled via partial correlation by the number of fulltime faculty. Number of students did not correlate with entrepreneurship (with number of faculty controlled), the lack of correlation probably due to necessarily using faculty size as the covariate.

Number of fulltime students and number of fulltime faculty in department (each standardized). Alpha =,87.

d(1) Bachelor's; (2) Master's; (3) PhD.

'Chair's perception.

'First-order partial correlation, controlled by wave of study.

second-order partial correlation, controlled by wave of study and number of fulltime faculty.

hFirst-order partial correlation, controlled by number of fullime faculty.

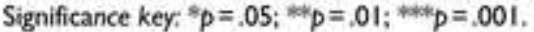

\section{Administrative support and statistical reasoning instruction}

The second research question addressed the relationships that administrative support might have with faculty entrepreneurship in teaching statistical reasoning and with the integration of statistical reasoning into the curriculum. Embedded in this question are the following: (1) How might the perceived constraints and benefits of statistical reasoning instruction for journalism students relate to chairs' willingness to reward faculty entrepreneurship? (2) Might administrators encourage this entrepreneurship by rewarding it? and (3) Might such entrepreneurship promote statistical reasoning integration into the curriculum? These three questions propose a potential path of relationships from the chairs' perceptions of benefits and constraints to his or her rewarding faculty entrepreneurship in teaching statistical reasoning in their classes, to more instances of 
NOT THE PUBLISHED VERSION; this is the author's final, peer-reviewed manuscript. The published version may be accessed by following the link in the citation at the bottom of the page.

entrepreneurship, to more integration of statistical reasoning instruction into the curriculum.

The structural equation models in Figure 1 (overall), Figure 2 (first wave), and Figure 3 (second wave) illustrate these paths and allow a comparison of results over time. Coefficients in these figures are standardized. All three models exhibit an acceptable level of goodness-of-fit to the data (root mean square error of approximation $($ RMSEA $)=.073, .056, .079$, respectively; goodness of fit index $(\mathrm{GFI})=.956, .953, .935$, respectively), although less than the ideal for a close fit. $\underline{7}$

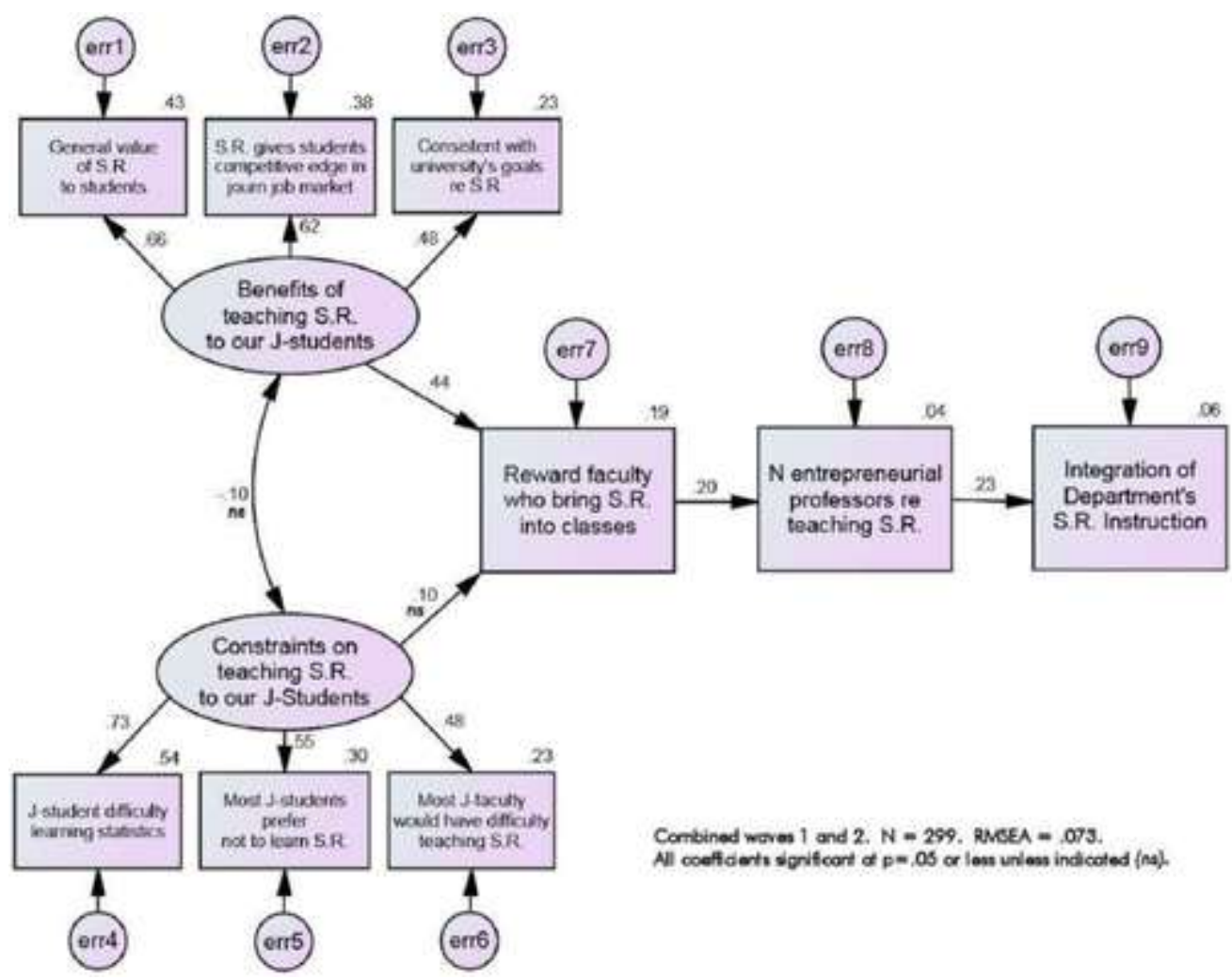

Figure 1. Model of chair rewards to faculty for statistical reasoning instruction (combined waves). 
NOT THE PUBLISHED VERSION; this is the author's final, peer-reviewed manuscript. The published version may be accessed by following the link in the citation at the bottom of the page.

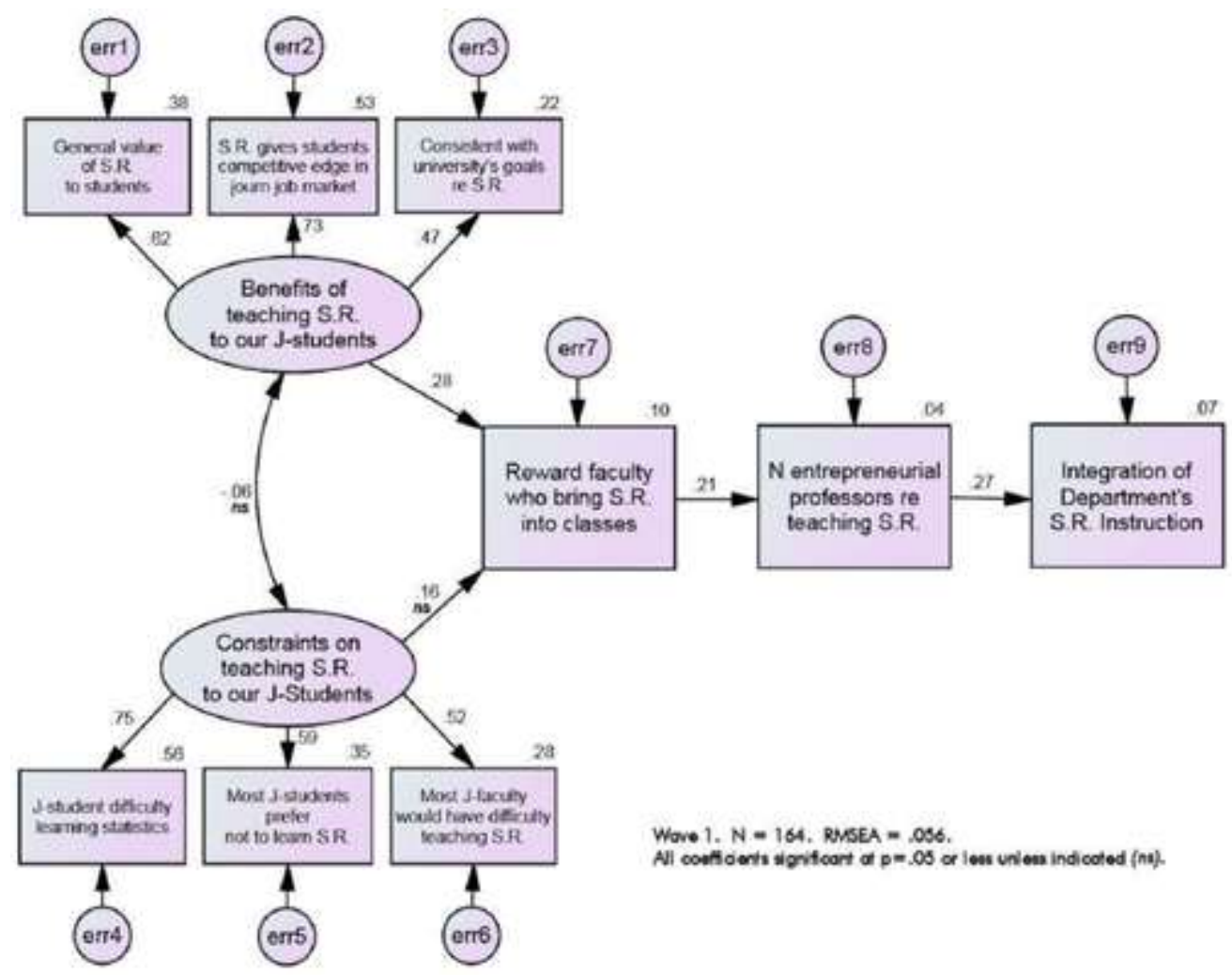

Figure 2. Model of chair rewards to faculty for statistical reasoning instruction (1997 wave).

Journalism: Theory, Practice \& Criticism, Vol. 17, No. 1 (January 2016): pg. 97-118. DOI. This article is (C) SAGE Publications and permission has been granted for this version to appear in e-Publications@Marquette. SAGE Publications does not grant permission for this article to be further copied/distributed or hosted elsewhere without the express permission from SAGE Publications. 
NOT THE PUBLISHED VERSION; this is the author's final, peer-reviewed manuscript. The published version may be accessed by following the link in the citation at the bottom of the page.

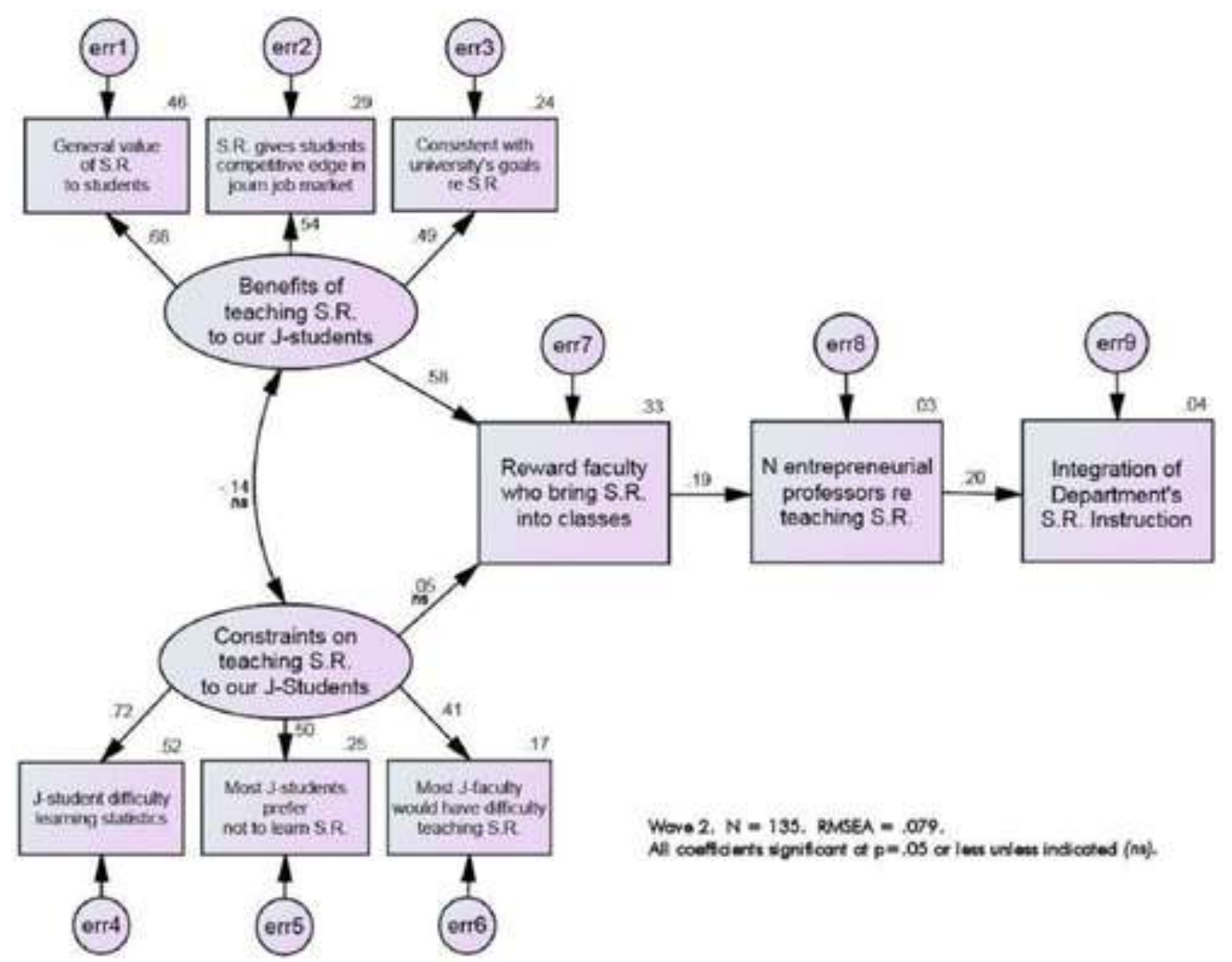

Figure 3. Model of chair rewards to faculty for statistical reasoning instruction (2008 wave).

\section{Benefits, constraints, rewards}

Based on the path coefficients in Figure 1, representing both survey waves combined, the perceived benefits of teaching statistical reasoning to journalism students (beta $=.44, p<.01$ ) generally appear to have played a bigger role than perceived constraints (beta $=.10$, ns) in the chairs' decisions to reward faculty for bringing such instruction into their classes. Comparing the results of Wave 1 (Figure 2) to Wave 2 (Figure 3), this difference appears to have strengthened over time. In addition, their perceptions of benefits (primarily) and constraints accounted for 10 percent $(p=.05)$ of the variance in their reward decisions in the first wave, but 33 percent $(p=.05)$ in the second wave. Thus, in considering rewards to their faculty for attempts at statistical reasoning pedagogy, the chairs seem to have given increasingly more weight over time to what they saw as the benefits of this instruction. 
The last rows of coefficients in Appendix 1 illustrate the relative contributions to the chairs' reward decisions of the separate considerations that constitute perceived benefits and constraints. The individual measures of perceived constraints played no significant role in reward decisions. The perceived benefit from being consistent with university-wide goals to teach statistical reasoning weighed about equally in the chairs' judgments in both waves of the study (Wave 1 partial $r=.27, p=.001$; Wave 2 partial $r=.33, p=.001$ ). However, the benefit of statistical reasoning to the journalism students themselves seems to have become more of a factor over time in the chairs' decisions. From the first to second wave, the chairs' perceptions of the general value of statistical reasoning to journalism students played a larger role in whether they would reward faculty who attempt to teach statistical reasoning to these students (Wave 1 partial $r=.15$, ns; Wave 2 partial $r=.36, p=.001$ ). Similarly, the chairs' beliefs that statistical reasoning skills would make students more competitive in the journalism job market became stronger factors in these reward decisions as well (Wave 1 partial $r=.17$, $p=.05$; Wave 2 partial $r=.35, p=.001$ ).

Appendix 1 also reveals that, despite these dynamics, the extent to which chairs reward faculty for attempts to teach statistical reasoning in their journalism classes had remained fairly low (a little over a quarter of the chairs say they did so) and essentially static over the time of the study. Similarly, the level of agreement or disagreement with the six items that represent benefits and constraints had remained stable over time. These similarities exist even though the respondents in the first wave are overwhelmingly different individuals from those in the second wave.

\section{Rewards, entrepreneurship}

Chair rewards to journalism faculty for teaching statistical reasoning were correlated positively with faculty attempting to do so (entrepreneurship). As noted in Figure 1, the relationship between reward and entrepreneurship is positive but fairly small (beta $=.20$, $R^{2}=.04, p=.01$ ) and had remained about the same in each wave of the study (Figures 2 and $\underline{3}$ ). The small number of faculty entrepreneurs did grow, however, from Wave 1 to Wave 2 
NOT THE PUBLISHED VERSION; this is the author's final, peer-reviewed manuscript. The published version may be accessed by following the link in the citation at the bottom of the page.

$\left(F_{1,293}=14.82, p=.001\right.$, as controlled in SPSS general linear model for differences in departmental staff size and other covariates).

\section{Entrepreneurship, curricular integration}

To what extent might entrepreneurship translate into the more formal integration of statistical reasoning instruction into the curriculum? As shown in Figure 1 , there is a statistically significant positive relationship between these two variables overall in the study (beta $=.23, p=.05$ ). This relationship did not vary markedly from Wave 1 (Figure 2) to Wave 2 (Figure 3). Chair rewards may relate positively to curricular integration, but only weakly and indirectly as a byproduct of the chairs' apparent encouragement of faculty entrepreneurship (AMOS standardized indirect effects $=.04, p=.05$ ). ${ }^{8}$ Overall, the model accounts for 6 percent of the variance $(p=.05)$ in curricular integration (Figure 1), although this appears to diminish slightly from 7 percent in Wave $1(p=.05$, Figure 2) to 4 percent in Wave 2 ( $p=.05$, Figure 3 ). The extent of curricular integration remained the same, however, from Wave 1 to Wave $2\left(F_{1,293}=1.37\right.$, ns, using SPSS general linear model to adjust for covariates).

\section{Discussion}

Overwhelmingly, journalism department chairs believed that it is important that their undergraduate students be able to reason with statistics, and at least two thirds said that students who have this cognitive skill enjoy a leg up in the journalism job market. According to some of the chairs, their universities give some priority to integrating statistical reasoning into the curriculum overall. Indeed, the chairs' single most preferred method of teaching statistical reasoning to undergraduate journalism students was to integrate this instruction across the journalism curriculum.

Yet requiring such instruction, as embedded into journalism courses, had remained comparatively and consistently low from the first to second wave of this study. The same was true of the scattering of entrepreneurial journalism instructors who made efforts to teach statistical reasoning - although more were known to their chairs to have made such attempts over time. 
NOT THE PUBLISHED VERSION; this is the author's final, peer-reviewed manuscript. The published version may be accessed by following the link in the citation at the bottom of the page.

Unfortunately, from the standpoint of trying to integrate statistical reasoning instruction across the journalism curriculum, a little over half of the chairs said that most of their faculty would find it hard to teach this material. To one extent or the other, many of the chairs also perceived that their students were unwilling to learn statistical reasoning or were unable to handle even basic statistical instruction at their universities. Nearly half said that the journalism curriculum was too tight to offer such instruction within the department.

Thus, given the push-and-pull dynamics of these factors, we further examined some of the characteristics that hallmarked those journalism programs offering in-house statistical reasoning instruction (scaled as: not at all, in elective courses, in required courses) and which housed entrepreneurial professors. Our analysis, of course, is limited by the questions we could include in a pair of fairly brief instruments, and to what the department chairs had reported in reply. Arguably, chairs (like others) make decisions on what they perceive to be true, including their perceptions of the various benefits and constraints related to teaching statistical reasoning to journalism undergraduates, and what would come of their rewarding instructors who attempt such instruction in-house. We can only assume that the chairs have adequate understanding of the content of courses offered in their departments and what their faculty are teaching.

\section{Structural factors, integration}

Initial findings were that larger programs, those which offered more advanced degrees, and those where the journalism curriculum was a bit more flexible (less tight) were somewhat more likely to integrate statistical reasoning into their curricula. For the most part, these same kinds of programs tended to nurture faculty entrepreneurship. While the reasons for these patterns are not clear, programs offering more advanced degrees may have more faculty intensely interested in research - including quantitative - than other programs, thus increasing the potential for providing students with exposure to statistical reasoning in the journalism curriculum. Curricular flexibility may provide more opportunities across the board

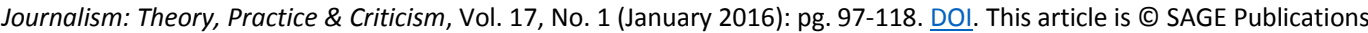
and permission has been granted for this version to appear in e-Publications@Marquette. SAGE Publications does not grant permission for this article to be further copied/distributed or hosted elsewhere without the express permission from SAGE Publications. 
NOT THE PUBLISHED VERSION; this is the author's final, peer-reviewed manuscript. The published version may be accessed by following the link in the citation at the bottom of the page.

for entrepreneurship and integrating statistical reasoning into the department's courses. $\underline{9}$

\section{Rewards, entrepreneurship, integration}

With the structural factors taken into account, we turned our attention to the potential role of the department chair in encouraging entrepreneurship. Recall that, with rare exceptions, the chairs surveyed in the first wave of the survey were different individuals than those surveyed in the second wave. Yet the chairs' attitudes toward the benefits from teaching statistical reasoning, and toward the constraints, were nearly identical in the two waves of the survey more than a decade apart.

It was not apparent from these results why chairs' perceptions of student and faculty constraints had no overall relationship with their desires to reward faculty efforts to teach statistical reasoning. Perhaps some chairs were dissuaded from encouraging the teaching of statistical reasoning in their departments by the obstacles to success they foresaw, whereas among other chairs, these same constraints only reinforced their desire to provide faculty with rewards for attempting to overcome them. Future research would have to sort out these beliefs. Notably, however, in deciding whether to reward faculty for entrepreneurship efforts, the chairs appear to have increasingly weighed, more heavily than constraints, their views toward the potential benefits of teaching statistical reasoning - especially whether this cognitive skill is important for the journalism students to learn and whether it might be advantageous for their future employability. 10

The two survey waves revealed no ultimate difference, however, in the percent of chairs $(26 \%, 29 \%)$ who said they reward faculty entrepreneurship to the extent that they can. Even though the chairs' attitudes toward statistical reasoning benefits became a more salient consideration in reward decisions, the fact that these attitudes themselves were essentially the same in both waves might help explain why their reward behaviors also remained the same. Nonetheless, despite this status quo, the bestowing of rewards was associated positively in both waves with entrepreneurship, which itself had increased over this period. One possibility is that reward efforts, even if constant, produced accumulated gains in faculty attempts to 
teach statistical reasoning over time. Given that a large amount of variance in entrepreneurship is unaccounted for by the model, certainly other unmeasured factors are affecting these faculty efforts. For example, in the absence of being able to provide rewards, some chairs may have otherwise encouraged or enabled faculty to teach statistical reasoning. Influences outside the department, such as professional or academic organizations and peers elsewhere, might have increased faculty interest in teaching statistical reasoning, or helped them enhance their abilities to do so. Hiring patterns and changes in faculty interests are also among potential explanatory factors. Further research would also be called for here.

Our survey does not permit us to determine why these chairs privilege embedded training over stand-alone courses in statistical reasoning. One possible reason is that they believe statistical reasoning can more easily be made relevant to statistics-averse students if it is incorporated into other types of training that these students seek. Chairs might also believe that students would learn statistical reasoning better if they encounter it repeatedly and in different course contexts. But more broadly, there seems to be a strong preference among education scholars for embedding skills training across a curriculum (see, for example, Bazerman et al., 2005; Bellon, 2000; Kasowitz-Scheer and Pasqualoni, 2002; Riordan et al., 2000; Sims, 2000), and these chairs may simply be reflecting that perspective.

Faculty entrepreneurship is also associated positively with the extent to which statistical reasoning instruction is more formally integrated into the journalism curriculum. In these cases, students would regularly be exposed to statistical reasoning in elective or required courses in topics such as computer-assisted reporting or research methods. Causal direction cannot be established from these data, of course, and as is true in regard to faculty entrepreneurship, the model accounts for only a relatively small amount of variance in this integration, so other factors besides structural variables and faculty entrepreneurship are probably at work. Nonetheless, a likely scenario, consistent with the results, is that chair rewards encourage faculty entrepreneurship which, in turn, leads to the more formal integration of statistical reasoning instruction into the journalism curriculum. Highly instrumental in the chairs' decisions whether to 
reward faculty who attempt such instruction is the extent to which the chair perceives certain benefits of statistical reasoning instruction for journalism students, including the general value of this learning for the students, its impact on their future employability in the profession, and the university's more general goals for incorporating this instruction across the curriculum.

\section{Follow-up research}

The results of this study suggest that follow-up research might employ models such as Icek Ajzen's (1988) Theory of Planned Behavior (TPB). A chair's support for faculty entrepreneurship, whether by direct rewards or other means, is a behavior, as is a faculty member's attempt to teach statistical reasoning to journalism students. TPB would help explore in greater detail the dynamics affecting these behaviors, and probably account for some additional variance in them beyond that found in this analysis. In examining the precursors of a person's intended and actual behavior, Ajzen's model incorporates the influences of perceived and actual control over performing the behavior (efficacy), the often subtle matter of perceived social pressures, and the individual's beliefs about the outcomes of a behavior as they relate to what he or she values. With some recasting onto the TPB formulation, the various potential benefits and constraints related to statistical reasoning instruction, as perceived by the chairs in this study, could be incorporated into research framed by the Theory of Planned Behavior.

Although longitudinal data relevant to this issue are quite rare, making comparisons of any kind valuable, the most recent survey in this particular longitudinal study was conducted more than 7 years ago. What might have changed since then? We suspect that elements that have not changed include the structural factors that were found to affect training patterns in our study. That is, larger, more resourcerich units are still more likely to invest in statistical reasoning training than will smaller units. And those journalism programs that provide graduate research instruction will field faculty with the training and motivation to push their students into this arena.

What has changed is the journalism occupation itself, which is morphing rapidly with an eye to journalists providing value-added 
content not easily accessible elsewhere. That trend could begin to place statistical reasoning more forcefully on the curricular table, even in smaller academic units. 'Data journalism' has become something of a buzz term among those seeking to reinvigorate journalism in the 21st century (Fink and Anderson, 2014; Lorenz et al., 2011), and journalism program chairs may well be responding to this clarion call if resources allow. Additionally, the acquisition of new faculty over time is likely to populate programs with professors who have both the interest in data analysis and the skills to offer statistical reasoning training to students. This study indicates that faculty entrepreneurship is aligned with more emphasis on statistical reasoning in the curriculum; new faculty hires are likely to make that relationship even stronger in the future.

\section{Facilitating statistical reasoning instruction}

Here are some suggestions to help administrators and faculty advance the teaching of statistical reasoning within journalism programs:

- Existing faculty with other established areas of expertise are unlikely to transform themselves into statistical reasoning aficionados. Programs that want to build in this area should encourage their local 'entrepreneurs' or, if such colleagues are not in place, may be better off hiring with this capacity in mind.

- Do not assume that your students are incapable of reasoning statistically, but do assume that many will be averse to such training. Moving them from 'averse' to 'interested' is an important initial challenge.

- A variety of publications have been produced to instruct journalists in computer-assisted reporting and data journalism, advances in investigative reporting that largely evolved from Philip Meyer's (1973, 2002) classic introduction of Precision Journalism to the profession. Some other sources, such as Charles Wheelan's (2013) book Naked Statistics, also provide examples, and humor, useful for class discussions of the applications of statistics to everyday life. Even if faculty are not teaching courses expressly devoted to data-based journalism, many such works provide examples and advice that can help faculty come to grips with the applications of statistical reasoning to journalism, and potentially feel more comfortable teaching it. 
- Online resources for statistical reasoning training continue to grow. Among those available now are sites such as DataDrivenJournalism.net, which bills itself as 'a hub for news and resources from the community of journalists, editors, designers and developers who use data in the service of journalism'

(http://datadrivenjournalism.net/about\#sthash.mKuyDdUn.dpuf ), and the 'Chance' project. The 'Chance' project was founded in the 1990s by Dartmouth College statistics professor Laurie Snell and his colleagues. 'The goal was to help students become critical readers of news stories that involve probability and statistical reasoning', explained the online newsletter of the American Statistical Association (1 March 2010). 'The project's constant has been its electronic newsletter, Chance News, which abstracts current news stories and suggests class discussion questions'. Since 2005, Chance News has been a wiki published several times a year by William Peterson and Jeanne Albert at Middlebury College in Vermont. It can be accessed at http://test.causeweb.org/wiki/chance/index.php/Main Page.

\section{Conclusion}

The era of 'big data', including unprecedented access to it for purposes of investigating and interpreting news, has come to newsrooms. In their recent national survey of working journalists, Wilnat and Weaver (2014) found that 28.1 percent of them would like more training in data journalism, third only to the percentage who wanted to learn more about social media engagement $(28.4 \%)$ and shooting and editing video (30.5\%), out of 23 possible topics for further training. And at one of the authors' universities, a senior editor of a major, Pulitzer-prize winning daily newspaper told student journalists in the fall of 2014 that he would prefer not to hire reporters who cannot work with data.

Within journalism, working with data is primarily a matter of statistical reasoning. Given that a journalist has a basic understanding of the principles underlying causality, statistics, and probability, various software programs can handle the calculations for him or her. How ready journalism students are for working in, and leading, the new professional world of data journalism depends on how ready journalism undergraduate programs are to prepare them to do so. That, in turn, may require some programs to change hiring 
NOT THE PUBLISHED VERSION; this is the author's final, peer-reviewed manuscript. The published version may be accessed by following the link in the citation at the bottom of the page.

preferences to favor new faculty who can integrate some statistical reasoning instruction into their journalism courses, or reward current faculty for doing the same. SAT data show that journalism students, on the average, are not math dummies. It might be best to avoid treating them as such.

Appendix 1 Descriptive statistics and partial correlations $\underline{a}$ among variables: Perceived benefits and constraints, chair support for teaching statistical reasoning to college-level journalism students.

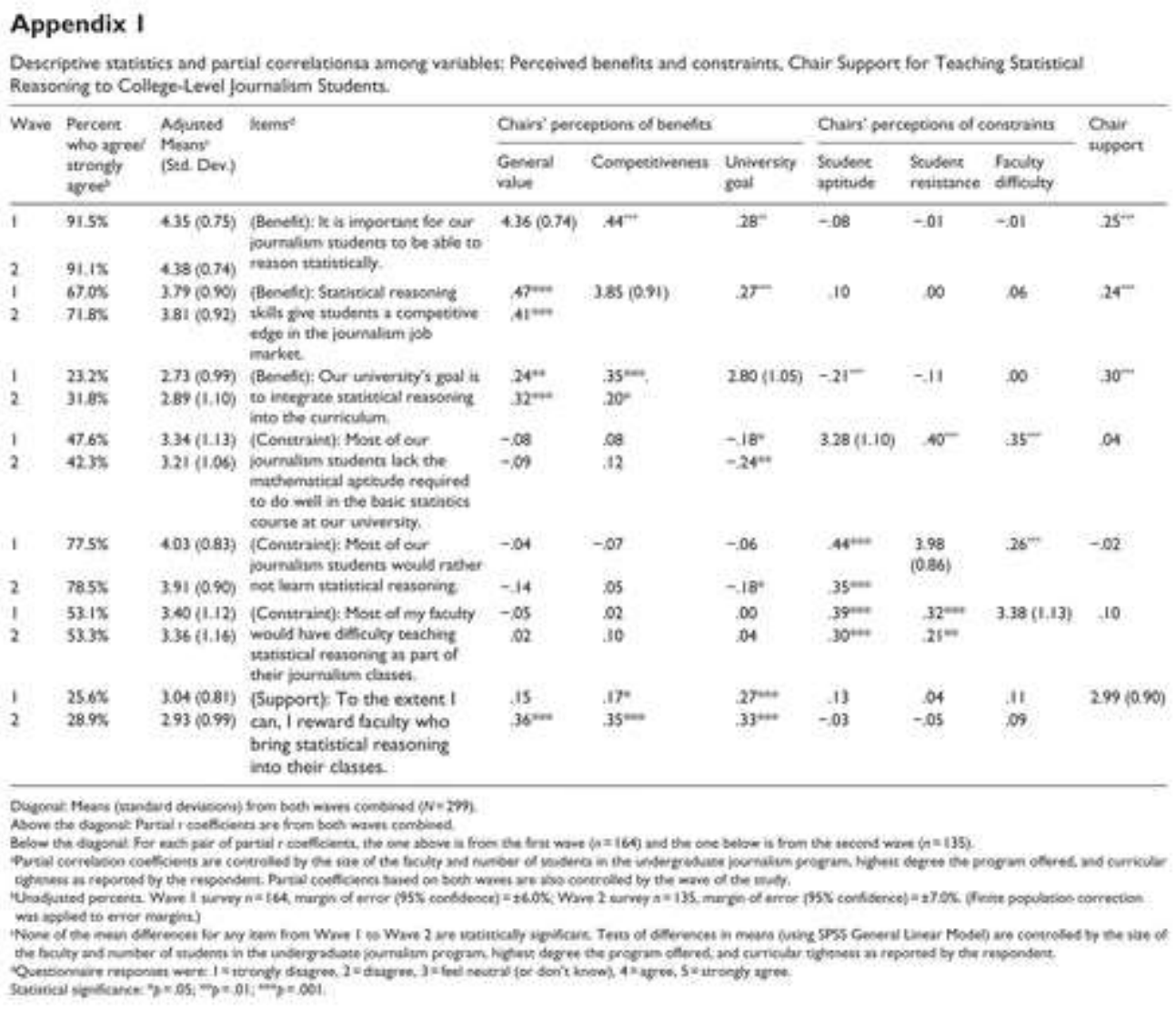

Declaration of Conflicting Interests The author(s) declared no potential conflicts of interest with respect to the research, authorship, and/or publication of this article.

Funding The author(s) disclosed receipt of the following financial support for the research, authorship, and/or publication of this article: The American Statistical Association provided funding for the 1997 survey. The 2008 survey was funded by an internal grant from the Diederich College of Communication at Marquette University, Milwaukee, WI, USA.

Journalism: Theory, Practice \& Criticism, Vol. 17, No. 1 (January 2016): pg. 97-118. DOI. This article is () SAGE Publications and permission has been granted for this version to appear in e-Publications@Marquette. SAGE Publications does not grant permission for this article to be further copied/distributed or hosted elsewhere without the express permission from SAGE Publications. 
NOT THE PUBLISHED VERSION; this is the author's final, peer-reviewed manuscript. The published version may be accessed by following the link in the citation at the bottom of the page.

\section{Notes}

${ }^{1}$ Neither of these abilities appeared in the educators' or professionals' top-10 lists of important skills for beginning journalists. It is not apparent from the report how the respondents were selected or contacted.

2Data from the College Board covering 2001-2005, as gathered by Dunwoody and Griffin (2013), showed an average verbal score of 507 for all college-bound seniors taking the Scholastic Aptitude Test and an average math score of 517. Among those intending to major in journalism, the average verbal score was 552 and the average math score was 514, effectively the same as the overall math average. Becker and Graf (1994) had found essentially the same results from earlier SAT data.

${ }^{3}$ These are the same sources used for the Annual Survey of Journalism \& Mass Communication Enrollments currently conducted by the Henry W. Grady College of Journalism and Mass Communication at the University of Georgia.

${ }^{4}$ Curricular tightness is a structural factor, but was measured as the judgment of the department chair, and so it is not an objective measure. When curricular tightness, essentially a structural constraint, was included in the exploratory factor analyses of perceived benefits and constraints, the result was a more complex, and less interpretable, three-factor solution. Therefore, to keep the benefits and constraints dimensions parsimonious while still taking curricular tightness into account, tightness was included in the analyses as a separate variable, primarily as a covariate as noted. Chairs were not asked to specify further whether they perceived curricular tightness as a matter of limited student choices or of constraints on faculty adding new courses or content to the curriculum.

${ }^{5}$ The latter constraints might, for example, be due to limits on credit hours allowed within the major, or because of a requirement to deliver other content within journalism courses.

${ }^{6}$ The correlation between program size and the level of degree offered is $r=.64, p<.001$.

${ }^{7}$ Goodness of fit for the latent variables measurement model was acceptable but mediocre (RMSEA $=.091$ for both waves combined, .080 for wave $1, .096$ for wave $2 ; \mathrm{GFI}=.971, .969, .960$ respectively). By excluding 
the 'constraints' latent variable and its three exogenous indicator variables, the goodness of fit for the entire SEM model improves overall, and for Waves 1 and 2 (respectively, RMSEA $=.027, .000, .059 ;$ GFI $=.988, .983, .969)$.

${ }^{8}$ The path data showed no significant direct relationship between chair rewards and the course integration variable within the models.

${ }^{9}$ The higher the degree the program offers, the more the chair disagrees that most of his or her faculty would have trouble teaching statistical reasoning as part of their journalism classes (partial $r=-.13, p=.05$, with the other control variables as covariates). The size of the program (partial $r=.07, \mathrm{~ns}$ ) and wave of the survey (partial $r=.00, \mathrm{~ns}$ ) are unrelated to this perception about faculty preparedness. Chairs who judge that their journalism curriculum is too tight to include statistical reasoning instruction also tend to agree that their faculty would have trouble teaching it (partial $r=.19, p=.001$ ).

${ }^{10}$ The 2008 wave took place in the wake of the national recession which weakened the job market for journalism and mass communication graduates (Becker et al., 2009). This fact may have primed chairs to consider more strongly than chairs did in 1997 the value that statistical reasoning abilities might add to students' employability.

\section{References}

Accrediting Council on Education in Journalism and Mass Communication (ACEJMC) (2012) ACEJMC accrediting standards. Available at:

https://www2.ku.edu/ acejmc/PROGRAM/STANDARDS.SHTML \#std2 (accessed 6 October 2014).

Ajzen I (1988) Attitudes, Personality, and Behavior. Milton Keynes: Open University Press.

American Statistical Association (2010) Amstat News, 1 March. Available at: http://magazine.amstat.org/blog/2010/03/01/chanceprojectma r10/ (accessed 4 October 2014).

Bazerman C, Little J, Bethel L (2005) Reference Guide to Writing across the Curriculum. West Lafayette, IN: Parlor Press LLC. 
Becker LB, Graf JD (1994) Myths and Trends: What the Real Numbers Say about Journalism Education. Arlington, VA: The Freedom Forum.

Becker LB, Vlad T, Olin D, . (2009) 2008 Annual Survey of Journalism \& Mass Communication Graduates. Athens, GA: Grady College of Journalism \& Mass Communication, University of Georgia.

Bellon J (2000) A research-based justification for debate across the curriculum. Argumentation and Advocacy 36(3): 161-173.

Cohn V, Cope L (2001) News \& Numbers: A Guide to Reporting Statistical Claims and Controversies in Health and Other Fields, 2nd edn. Ames, IA: Wiley-Blackwell.

Curtin PA, Maier SR (2001) Numbers in the newsroom: A qualitative examination of a quantitative challenge. Journalism \& Mass Communication Quarterly 78(4): 720-738.

Cusatis C, Martin-Kratzer R (2010) Assessing the state of math education in ACEJMC-accredited and non-accredited undergraduate journalism programs. Journalism and Mass Communication Educator 64: 356-377.

Dunwoody S, Griffin RJ (2013) Statistical reasoning in journalism education. Science Communication 35(4): 528-538.

Finberg HI, Klinger L (2014) Core Skills for the Future of Journalism. St. Petersburg, FL: The Poynter Institute for Media Studies.

Fink K, Anderson CW (2014) Data journalism in the United States: Beyond the 'Usual Suspects'. Journalism Studies. Epub ahead of print 8 August. DOI: 10.1080/1461670X.2014.939852.

Galesic M, Garcia-Retamero R (2010) Statistical numeracy for health: A cross-cultural comparison with probabilistic national samples. Archives of Internal Medicine 170: 462-468.

Garfield J (1998) The statistical reasoning assessment: Development and validation of a research tool. In: Piereira-Mendoza L (ed.) Proceedings of the fifth international conference on teaching statistics. Voorburg: International Statistical Institute, pp. 781786.

Garfield J, Gal I (1999) Teaching and assessing statistical reasoning. In: Stiff LV (ed.) Developing Mathematical Reasoning in Grades $K-12$. Reston, VA: National Council of Teachers of Mathematics, pp. 207-219. 
Henderson JJ, Christ WG (2014) Benchmarking ACEJMC competencies: What it means for assessment. Journalism and Mass Communication Educator 69(3): 229-242.

Hijmans E, Pleijter A, Wester F (2003) Covering scientific research in Dutch newspapers. Science Communication 25(2): 153-176.

Kasowitz-Scheer A, Pasqualoni M (2002) Information literacy instruction in higher education: Trends and issues. Library and Librarians' Publication, paper no. 34. Available at: http://surface.syr.edu/sul/34

Livingston C, Voakes PS (2005) Working with Numbers and Statistics: A Handbook for Journalists. New York: Routledge.

Lorenz M, Kayser-Bril N, McGhee G (2011) Voices: News organizations must become hubs of trusted data in a market seeking (and valuing) trust. NiemanLab, 1 March. Available at: http://www.niemanlab.org/2011/03/voices-news-organizationsmust-become-hubs-of-trusted-data-in-an-market-seeking-andvaluing-trust/ (accessed 30 December 2014).

Maier SR (2002) Numbers in the news: A mathematics audit of a daily newspaper. Journalism Studies 3(4): 507-519.

Maier SR (2003) Numeracy in the newsroom: A case study of mathematical competence and confidence. Journalism \& Mass Communication Quarterly 80(4): 921-936.

Meyer P (1973) Precision Journalism: A Reporter's Introduction to Social Science Methods, 1st edn. Bloomington, IN: Indiana University Press.

Meyer P (2002) Precision Journalism: A Reporter's Introduction to Social Science Methods, 4th edn. Lanham, MD: Rowman \& Littlefield.

Riordan DA, Riordan MP, Sullivan MC (2000) Writing across the accounting curriculum: An experiment. Business Communication Quarterly 63(3): 49-59.

Sims RL (2000) Teaching business ethics: A case study of an ethics across the curriculum policy. Teaching Business Ethics 4(4): 437-443.

Voakes PS (2006) Math and statistics. In: Christ W (ed.) Assessing Media Education: A Resource Handbook for Educators and Administrators. New York: Routledge, pp. 261-280. 
Wheelan C (2013) Naked Statistics: Stripping the Dread from the Data, 1st edn. New York: W. W. Norton \& Company.

Wilnat L, Weaver D (2014) The American Journalist in the Digital Age: Key Findings. Bloomington, IN: School of Journalism, Indiana University.

\section{Author biographies}

Robert J Griffin (PhD, University of Wisconsin-Madison) is Full Professor in the Diederich College of Communication at Marquette University in Milwaukee, Wisconsin, USA. He focuses much of his teaching and research on communication about environment, energy, health, science, and risk. He is a recipient of Marquette's Faculty Award for Teaching Excellence, awarded to the university's top educators. In 2007, he was elected a fellow of the American Association for the Advancement of Science.

Sharon Dunwoody (PhD, Indiana University) is Emeritus Professor of Journalism and Mass Communication at the University of WisconsinMadison, USA. She studies the construction of science and environmental messages, as well as the ways in which individuals use such messages to inform their judgments about science issues. She is a fellow of the American Association for the Advancement of Science, the Society for Risk Analysis, and the Midwest Association for Public Opinion Research. 